\title{
DEVELOPMENT OF ADMINISTRATIVE LAW AND ADMINISTRATIVE LEGAL DOCTRINE IN LITHUANIA
}

The system of national law and the corresponding system of democratic authorities had to guarantee optimal protection of the individual's fundamental freedoms and rights, and help to create human welfare. Science of administrative law is constantly evolving, and its insights are strategic in nature, oriented towards the future. There is often a struggle for new ideas, opinions, concepts, paradigms to be embedded or denied. The new, old, inaccurate statements are changed to be more accurate, the new ideas criticize the old ones, and life practices raise new problems that science must answer rationally. The science of administrative law in Lithuania is not static, it is constantly changing as the administrative law itself changes. The concept of administrative law is changing, its regulation is expanding. The science of administrative law is an integral part of Lithuanian law science, where the specialists of administrative law-scientists investigate the essence of this branch of law, its subject matter and separate institutes and in general all actual problems of administrative legal practice and science of the whole country.

This article is the first scientific research in the cycle of articles "Development of Administrative Law and Administrative Legal Doctrine in Lithuania".

The purpose of this article is to present the development of administrative law and administrative law doctrine in Lithuania since 1990 by analysing the works of Lithuanian scientists in this field through the categories defined in the research tasks. In order to achieve the aim of the article, the following tasks are raised: briefly to introduce and discuss the development of Lithuanian administrative law science and administrative law as a category, to define and analyse the goals of administrative law, the subject of regulation and the system of administrative law in Lithuania. In order to achieve the aim and tasks of the research, the analysis of the works of Lithuanian scientists and the main laws implementing the administrative legal regulation of Lithuania was performed.

Methods. Historical comparative, documents' analysis, synthesis and other methods were used for research.

Results of research showed that Lithuania has modern administrative law and administrative justice system, that meets nowadays meets and European Union justice standards'requirements.

Conclusions. We can conclude that Lithuanian scientists understand the administrative law in broad sense as law of management and described quite wide range of its regulation subjects. After Lithuania's accession to the European Union and its commitment to take over its acquis communautaire, the entire Lithuanian legal system, together with administrative law, had to adapt to change. Implementation of the provisions of the European Union legislation in Lithuanian law has become a priority. The abundance of administrative legal regulation at European Union level and the need for its application in the case-law have created challenging tasks for administrative law science. An accurate analysis of the implementation of European Union legislation in the systems of state power and public administration in Lithuania, analysis of administrative legal systems of the Member States of the European Union, search for similarities and differences, effective defence of the rights and legitimate interests of a person when a Member State misapplies (waives) the provisions of European Union legislation, the jurisdiction of national courts to deal with damages where, for example, damage caused by inappropriate application of European Union law is made by a court of final instance in the state, and other issues become the subject of modern administrative law research.

Key words: administrative law science, administrative law, public administration, administrative justice, legal doctrine. 


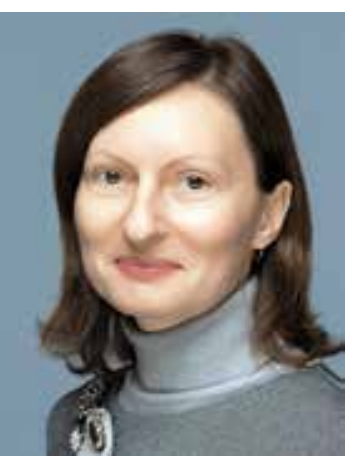

Egle Bileviciute, Professor of Public Law Institute of Law School of Mykolas Romeris University orcid.org/0000-0003-4142-3774 eglek@mruni.eu; eglutebil@gmail.com

\section{Introduction}

The purpose of administrative legal research is to reveal the essence, regularities and peculiarities of development of legal ideas, legal norms and legal practice, and to reveal the tendencies of development of administrative law doctrine and justice. After the restoration of the independence of Lithuania the task was to reform the existing Soviet legal system, to prepare new laws of the Republic of Lithuania that would meet the needs of the public administration of a democratic legal state, to harmonize national laws with the provisions of international acts and to foresee their development perspectives of legal regulation. Thus, the system of national law and the corresponding system of democratic authorities had to guarantee optimal protection of the individual's fundamental freedoms and rights, and to help to create human welfare. The mentioned reasons influenced that the more attention at the concept of administrative law, the legal institutes regulated by it, the development of this branch of law, social changes and their influence on the administrative legal regulation was given only after the restoration of Lithuania's independence in 1990.

The science of administrative law is an integral part of Lithuanian law science, where the specialists of administrative law - scientists investigate the essence of this branch of law, its subject matter and separate institutes and in general all actual problems of administrative legal practice and science of the whole country. The science of administrative law, as well as one of its research objects - administrative law, is not static, unchanging. Changing public legal relations, values that are fostered in society, administrative law, its goals and objectives are also changing. The administrative law science must also develop accordingly, actively participates in the development of methodological foundations of administrative law, in the development of institutes and legal norms of this branch of law, as well as in forecasts and proposals on how to effectively implement the state administration.

This article is the first scientific research in the cycle of articles "Development of Administrative Law and Administrative Legal Doctrine in Lithuania". The purpose of this article is to present the development of administrative law and administrative law doctrine in Lithuania since 1990 by analysing the works of Lithuanian scientists in this field through the categories defined in the research tasks. In order to achieve the aim of the article, the following tasks are 
raised: briefly to introduce and discuss the development of Lithuanian administrative law science and administrative law as a category, to define and analyse the goals of administrative law, the subject of regulation and the system of administrative law in Lithuania. In order to achieve the aim and tasks of the research, the analysis of the works of Lithuanian scientists and the main laws implementing the administrative legal regulation of Lithuania was performed.

2. Development of administrative law doctrine and administrative law as category in Lithuania

Of course, administrative law, as a branch of public law, regulates the public relations that exist in the field of public administration. The norms and principles of administrative law must not be immobile, without development, as if they are "going by themselves" because they would soon become insignificant. The collecting, analysing, researching, systematising knowledge of administrative law, improving the theoretical foundations of administrative law, its institutes, concepts and categories are the main task of administrative law science. The essential feature of the science of administrative law lies in its the methods, that administrative law science uses to study social legal objects. Another important feature of this science is the development of administrative law theories, scientists not only provide research data, but seek to explain them based on a certain theory.

In the interwar Lithuania (1918-1940), the main focus of administrative law science was on the systematization of laws and post-statutory legislation in the field of administrative law, but also published articles, monographs, and lectures sought actively investigate administrative law and its institutes (Administrative law, 1939). Particularly important contributions to the administration law science during the interwar period were the works of Mykolas Riomeris (Riomeris, 1994). After the establishment of the Soviet government and Soviet ideology in Lithuania in 1940, the independent development of Lithuanian administrative law was prevented. The lack of researchers in this field, limited sources of administrative law - normative acts issued by the relevant government departments of the respective councils, prevented the progressive development of Lithuanian administrative law science. The restoration of the independence of the Republic of Lithuania has led to fundamental changes in all areas of public life, including administrative law and public administration. The latter had to adapt to the new state governance system, to move from advocating Soviet ideology to a democratic system based on human rights.

Since 1990, developing administrative law science concerning the questions of the concept of administrative law and public administration, Lithuanian administrative law issues and problems has been discussed in many works: the "Administrative law" manual published by the collective of authors (Bakaveckas, et al., 2005), A. Andruškevičius works "Administrative law: general theoretical issues, institute of management acts, legal aspects of conflict relationships" (Andriuškevičius, 2008) and "Principles and boundaries of norms of administrative law" (Andriuškevičius, 2004), in A. Bakaveckas handbook "Administrative law: theory and practice. Part I "(Bakaveckas, 2012), E. Bilevičiūtè "Development of administrative law science in Lithuania" (Bilevičiūtè, 2013), in the A.P. Čiočys handbook "Basics of law" (Čiočys, 2008), I. Deviatnikovaite "Administrative law: categories, definitions, tasks" (Deviatnikovaite, 
2009), J. Paužaitè-Kulvinskienė work "Administrative justice: theory and practice" (Paužaitė-Kulvinskienè, 2005), B. Pranevičienè work "Quasi-court institutions in administrative control system" (Pranevičienè, 2003), "History of Lithuanian law" (Andriulis et al., 2002) manual published by the collective of authors and others. Separate aspects of administrative law are discussed in scientific collective monograph "Human Rights, the Rule of Law and Administrative Justice" (Piličiauskas, 2012), in scientific articles of Algimantas Urmonas "Administrative law in area of social changes" (Urmonas, 2006), "Social interactions of administrative law" (Urmonas, 2010), "Administrative Law as a Macro-System Phenomenom" (Urmonas, 2009), "Searching for the application of conceptual models of social technologies in administrative law" (Urmonas, 2007), M. Maksimaitis "Law science in Lithuania in Soviet times: achievements and looses" (Maksimaitis, 2007), D. Urmonas "Origins of administrative jurisdiction in Lithuania" (Urbonas, 2009), D. Žilinskas, "Will we tackle the tree from top?" (Žilinskas, 2000), E. Bilevičiūtė and V. Kosmačaite "Global administrative law", (Bilevičiūtè, Kosmačaitè, 2013) and others.

Not only the legislator and public administration entities, but also administrative law science is creating and developing administrative law, is solving the problems arising in field of public administration and governance of the state. The main object of this science is administrative law as a branch of law. However, the study of the legal norms of this branch is not limited to administrative law. The science of administrative law in the broad sense is the system of cognitive researches results of one or another country, reflecting state governance, theoretical and methodological foundations of this process, its principles, basic ideas and traditions. Today's Lithuanian administrative law science seeks to clarify, summarize and present various recommendations (proposals) in the organization and implementation of the public administration of the state. The science of administrative law is an integral part of Lithuanian law researches the essence, subject and separate institutes of administrative law. The clear definition of these concepts, the determination of their content and attributes, and the establishment of relations with social management and advanced administrative legal ideas and concepts in scientific publications (textbooks, monographs, materials of scientific practical conferences, articles collections and other literature) generally create the subject of Lithuanian administrative law. Today's Lithuanian administrative law, as a branch of law and a discipline of teaching, is fundamentally reformed as its system and subject matter of legal regulation is changing, especially the norms of substantive and procedural administrative law are intensively developing (changing and supplementing).

Thus, administrative law, as a branch of law and as science, is closely linked, but far from being identical. Administrative law, as well as administrative law science, is interested in the relationships that exist in the field of public administration. However, the science of administrative law also analyses the administrative legal categories, formulates the concepts of administrative law, examines its norms, examines the regularities of state administration, the practice of the executive authorities, as well as the connections between administrative legal relations, the practice of the implementation of the norms of administrative law, the functioning of administrative institutions, prepares forecasts of the development of legal norms, makes recommendations for improvement of norms 
and administrative legal relations, prepares codification programs, theoretical basis for interpretation of norms, helps to improve state management mechanism. The science of administrative law is interested in the historical perspectives and tendencies of the development of administrative law as a branch of law and as a science, examines the theories and views of various scientists, the reasons for their emergence, and compares the administrative law of foreign countries.

Of course, it should be emphasized that the most important element of the subject of administrative law science is administrative law (current and valid administrative regulation). However, as we have already mentioned, the concept of the subject of administrative law will be incomplete if it is not supplemented by research into the application of administrative legal categories and administrative law in practice. Scientific researches on subjects of legal relations, as well as legal facts, vertical and horizontal, material and procedural, internal and public administration relations, aspects of state administration today, executive management activities of the governing institutions in application of legislation are particularly important, researches should be close with social practice, with purpose to improve the legal framework effectively. The subject of administrative law science is closely related to the practice of administrative legal regulation (especially in the field of public administration) (Bakaveckas et. al., 2005). Thus, it can be summarized that the science of administrative law investigates the doctrines of administrative law (ideas, tendencies, regularities of public administration, etc.), norms and practices of administrative law and simulates the tasks (perspectives) of public administration. Particularly topical for administrative law researchers is question of ensuring the rule of law - legality and justice - in administrative justice and jurisdiction by interpreting the true meaning of administrative legislation, guaranteeing the legal status of parties, their representatives, experts, lawyers, and other involved persons (Bakaveckas et. al., 2005).

The restoration of independence of the Republic of Lithuania has led to changes in all areas of society. In the short term, a major reform was needed in the fields of public administration, regulation of property legal relations, judicial activity and other areas. Article 5 of Constitution of Republic of Lithuania of 1992 October, 25 adopted the provision that the State institutions shall serve the people" (Constitution of the Republic of Lithuania, 1992). Essential policy decisions as one of the first objectives of the reform included public administration and the judiciary (including the establishment of administrative courts). The old administrative institutions were seen as a benchmark for rigidity, unprofessionalism (Bakaveckas et. al., 2005). After the restoration of the independence of the Republic of Lithuania, the entire system of public administration had to be re-established. We needed to take Western experience of public administration quickly and without major shocks. The process was complex and hasty. Lithuania, having freed itself from the Soviet (Eastern) state administration system, did not have independent state life experience. Western public administration experience was difficult to reconcile with the nomenclature (inherited from the Soviet past), closed and corrupt in the post-Soviet administration of Lithuanian institutions. In addition, the restored Lithuanian state could not take over the interwar Lithuanian public administration experience. The tradition of improving the administration of state institutions was terminated by the Soviet occupation. On the other hand, in 1990, The Republic of Lithuania has chosen the path 
of democratic development, and in the interwar period Lithuania, the last fourteen years of its existence, has been an authoritarian state. Another reason that prevented Lithuania from taking over administrative management from the interwar period was that in the area of public administration Lithuania had conceived the main reforms in the 20th century, in the early and mid-1990s (Smalskys, 2010).

Thus, a new, modern and efficient mechanism of the public administration system was needed. The main idea was to seek state quality. Objectives such as simplicity, bringing solutions closer to citizens, and greater state responsibility have been highlighted. These goals were related to Lithuania's aspiration to become a member of the European Union, to strengthen administrative capacity and to make effective use of European Union support in the area of public administration reform (Smalskys, 2010). Thus, after the restoration of the independence of the Republic of Lithuania, a large-scale reform of the public administration system was implemented, which, however, had many shortcomings and had to be improved.

One of the most important reforms of the judiciary is administrative courts' establishment in 1999. As a conceptual basis for the establishment of these courts, the provision of Paragraph 2 of Article 111 of the Constitution of the Republic of Lithuania has established that specialized courts may be established for the examination of administrative, labour, family and other categories of cases (Constitution of the Republic of Lithuania, 1992). It should be noted that together with the Law on Administrative Proceedings (Law on Administrative Proceedings of the Republic of Lithuania, 1999), the Law on Administrative Disputes Commissions (Law on Pre-Trial Administrative Disputes Procedure of the Republic of Lithuania, 1999), which introduced the pre-trial investigation of administrative disputes, came into force.

So, Lithuania has special administrative courts' system and also the developed system of pre-trial hearing and investigation of administrative disputes.

A regional administrative court is the court of special jurisdiction established for hearing complaints (petitions) in respect of administrative acts and acts of commission or omission (failure to perform duties) by entities of public and internal administration. Regional administrative courts hear disputes in the field of public administration, deal with issues relating to the lawfulness of regulatory administrative acts, tax disputes, etc. Before applying to an administrative court, individual legal acts or actions taken by entities of public administration provided by law may be disputed in the pre-trial procedure. In this case disputes are investigated by the Lithuania Administrative Dispute Commission or Tax Dispute Commission. The Supreme Administrative Court is first and final instance for administrative cases assigned to its jurisdiction by law. It is appeal instance for cases concerning decisions, rulings and orders of regional administrative courts, as well as for cases involving administrative offences from decisions of district courts. The Supreme Administrative Court is also instance for hearing, in cases specified by law, of petitions on the reopening of completed administrative cases, including cases of administrative offences. The Supreme Administrative Court develops a uniform practice of administrative courts in the interpretation and application of laws and other legal acts. The practice of administrative courts of Lithuania is also the part of administrative law doctrine. 
Administrative law is one of the most significant branches of modern law, because it regulates a very wide spectrum of social field. From the fields of social tension in political relations and processes, social contradictions are manifested, which transform into analogous tension in law - fields of legal tension: legal disputes at macro and micro levels (Urmonas, 2009). Due to constant social changes, it is not possible to provide a single definition of administrative law, to clearly define its subject. That is why it is not easy to define the subject of its regulation because it is intertwined with other legal rights - constitutional, criminal, tax, financial, civil, labour, environmental (ecological), construction.

Ieva Deviatnikovaite defines administrative law as part of a public law, the norms of which regulate relations arising in the exercise of their powers by the public administration, i.e. by allowing sub statutory acts to be implemented in laws, monitoring compliance with their decisions, and carrying out internal controls, administrative services, organisation of public service activities, internal administration (Deviatnikovaite, 2009).

A. Andruškevičius proposes to determine the scope of administrative law (Andriuškevičius, 2004). They reveal the purpose of the branch of the law. Moreover, it is possible to define administrative law easily, i. e. the scope of validity becomes a methodological basis for the definition of this branch of law. Administrative law is a part of public law whose norms regulate: the system of public administrations, relations between them, functions, status of civil servants; relations between human/persons and public administrations; control of the activities of public administration entities; the examination of administrative disputes between man/persons and public administrations.

More definitions of administrative law of the same scientist are given: "administrative law is a set of specialized norms and principles of public law, which is used to establish the institutional structure and subordinate relations of public administration, defining the activities and methods of this administration in the field of management relations with individuals, as well as organizing the litigation of public and administrative public administration disputes in courts and other state institutions" (Andriuškevičius, 2008). The author admits that he deliberately does not describe administrative law as an independent branch of law, because it is closely related to other legal rights: "administrative law - a part of public law whose norms and, in their absence, the principles of law, define: 1) to whom and to what authority to require the conduct of participants in legal relationships that are not contrary to the interests of society and the state; 2 ) to whom and by what means, by lawful means, to force participants in a legal relationship to behave in a manner contrary to the public and public interest; 3 ) who has been given the power to settle the dispute if he arises between claiming unlawful conduct and those subject to such a claim" (Andriuškevičius, 2004). The scientist points out that he perceives administrative law not only as a norm but also as a rule, as a set of principles. This is based on the fact that the principles represent a "qualitative side of this branch of law". In addition, the principles are a "stabilizing factor in administrative law". It is possible to get information from the norms that reveal only the "instantaneous state", because the laws are very often changed, filled, destroyed (Andriuškevičius, 2008).

Professor A. Vaišvila describes administrative law as branch of law regulating the public relations that arise in the performance of state institutions in compliance with 
the requirements of the constitution and laws. It defines the structure and competence of public administration entities of ministries, departments, municipalities, their relations with citizens in managing and supervising economic and other activities of citizens and their associations. Scientist distinguishes its subject - human relationships arising from economics, science, education, health care, law enforcement, national defence, protection of citizens' rights and other areas, and an approach based on the principle of authority and subordination, which is expressed through binding orders and instructions, subordination of services, disciplinary, official responsibility for the area of activity entrusted (Vaišvila, 2004). Professor Audrius Bakaveckas says that in scientific literature, administrative law is usually described as a management law, because it regulates the public relations that arose in organizing and implementing the executive, state and public administration (administration). As part of public law, this branch of law is considered to be a tool for the management and regulation of social processes in the public sector, and the subject of its regulation is public administration (Bakaveckas, 2007; Bakaveckas, 2012). Professor Urmonas gives some detailed definitions of administrative law: "administrative law is a branch of law that is composed of legally significant human, social, state social values, regulated by state administration, their legitimate means of implementation and protection, and the rules of administrative law on the basis of social justice, regulated by natural and legal persons, with the participation of public administration institutions, activities (Bakaveckas et. al., 2005).

\section{Tasks of administrative law}

Legislative regulation has some goals. It has been mentioned that administrative law regulates the managerial relations between persons and public administration entities, which are established by the latter in the exercise of the powers provided for in the Constitution, laws and other legal acts. Thus, the purpose of administrative legal regulation is to achieve one of the main goals - to reconcile the interests of opposing groups in seeking a social compromise.

Hence, the balance between individual and societal interests must be maintained in the compromise. The regulatory impact of administrative law must be directed towards individuals in a way that combines individual and public interests and meets public interests. It can therefore be said that the main purpose of administrative law is to create a model of administrative legal regulation (normative) that would ensure the reconciliation of the interests of individuals, their groups and society.

Here A. Andriuškevičius argues that "current administrative law is a set of principles and legal norms, the main function of which is the safeguarding and protection (defence) of mutual public interests (connecting the needs of both the state and society). The task of this branch of law is to provide citizens with effective legal possibilities to defend themselves against unlawful actions of public administration" (Andriuškevičius, 2004). He gives the following concepts of administrative law: "administrative law - a measure of protection of public interests", "a measure of prevention of conflicts of public interest", "administrative law has no more important task than harmonization of relations between human and executive power" (Andriuškevičius, 2004). The scientist argues that the purpose of administrative law is not only to establish the status of institutions of public administration, but also to perform the function of prevention of public conflicts. This 
means that the institutes of this branch of law have to establish principles that would prevent public administration from taking decisions ignoring the public interest. So, there is another purpose here: administrative law rules must set up mechanisms for overseeing the public interest to ensure the effectiveness of the principles. Here the author emphasizes the role of courts in solving disputes between individuals and public administration (Andriuškevičius, 2008). Emphasizing the mission of administrative law, A. Urmonas believes that it "must serve the public interest in a coordinated manner, ensuring personal protection, cultural development, economic development $\langle\ldots\rangle$, is not enough to define the mission alone, it is no less important to perceive it in the context of social change. Since social life is not stable, constantly changing, refusing certain values and replacing them, therefore, the change of mission must be ensured so that it does not lag behind the reality and not become formal" (Urmonas, 2006). So, the administrative law has very important goal - to be flexible and constantly reflect reality and the needs of today's people (Deviatnikovaité, 2009).

It may be concluded that the aim of administrative law is to combine public and private interests. This objective can be divided into three elements: the subject of administrative law is the public interest. According to some authors, the subject of its regulation is public administration (Bakaveckas, 2007), and the aim of the public administration institutions themselves is to serve the public interest of individuals; function of administrative law - coordination of public interests; the task of administrative law is to create opportunities and means to defend against the actions of illegal public entities.

A. Andruškevičius argues that public interests are an informal subject of administrative law, and the coordination and prevention of their conflicts is a general function of this right. Thus, he specifies the functions of administrative law as the regulation, protection of personal rights, repressive, educative (Andriuškevičius, 2004). The regulatory function manifests itself in the fact that public administrations regulate the behaviour of individuals. Thus, public entities impose legal obligations, perform their duties by giving individuals access to subjective rights. The repressive function manifests itself in the fact that public administration entities may not only grant a license, but also withdraw it or terminate particular activities if the legal norms are violated. This function eliminates negative, dangerous public relations.

\section{Subject of administrative law in administrative doctrine in Lithuania}

The subject of administrative legal regulation is particular public relations. A number of legal entities are involved in these relationships: public authorities (not only executive but also legislative and judicial); subjects of local self-government (municipal councils, mayors, municipal administrators, municipal controllers, elders of municipalities, heads of municipal enterprises, budget institutions, etc.); regulatory authorities (National Audit Office, Parliament Ombudsmen, Bank of Lithuania, State Commission of the Lithuanian Language, Chief Official Ethics Commission, Competition Authority); non-governmental organizations (non-governmental), state-owned enterprises entrusted with the performance of appropriate public administration functions such as transport registration; dispute settlement commissions/quasi-judicial bodies (Lithuanian Administrative Disputes Commission, Municipalities, Tax Disputes Commission) (Andriuškevičius, 2002). And, obvious, natural persons, private legal persons are closely related to administrative legal 
relations. The purpose of the above-mentioned institutions is to harmonize the interests of these persons with the public and to satisfy the public interest.

Administrative legal relations are regulated by various methods: imperative, dispositional, equality of parties, promotion, persuasion, etc. It is wrong to assume that only the imperative method dominates in administrative law, because this branch of law cannot be identified only with administrative violations of law and administrative penalties. But administrative legal relations usually arise when a legal rule arises. And this is a feature of the imperative method. However, there is also a method of equality between sides. It is the duty of the public administration to serve the people, that the principles of publicity and transparency are very important in administrative relations. It is possible to initiate relationships with public entities themselves - to apply for information, to request it, to apply to administrative courts or administrative dispute commissions to decide what is right and to apply for a license. In all of these relationships, we are equal and equal parties, and public actors must perform their duties. There may be an incentive method in administrative legal relations. Administrative legal relationships can encourage a wide range of individuals and may lead to administrative agreements.

\section{System of administrative law in administrative law doctrine in Lithuania}

In Lithuania, administrative law is perceived as a whole of two parts - general and special. Some authors separated all administrative law in two parts as material norm part (administrative law) and process norms (administrative procedure) (Andriuškevičius, 2008). The general part of administrative law unites legal norms, institutes regulating the "general legal status of subjects of administrative legal relations" (Andriuškevičius, 2008). The general part sets out the basic principles of administrative law, analyses the relationship between them and the principles of constitutional law the rule of law, the state of social welfare, separation of powers, legitimacy, proportionality, equality before the law. Sources of administrative law, types of administrative acts, their purpose. These are norms that establish the principles of administrative law institutes, the principles of public administration, the administrative legal status of institutions, the administrative legal status of civil servants, non-governmental organizations (associations, public institutions, public organizations, charity and support funds) and citizens and aliens in the field of public administration or public administration. These norms also establish the foundations of the civil service, the forms and methods of management activity, the methods of control and supervision, the ways and procedure of ensuring legitimacy in the field of public administration, the foundations of administrative justice. The research of the institutes of the general part of the administrative law covers the issues of the significance of public administration, establishes the system of public administration institutions, mutual arrangement, relationship, competence, the principles which these institutions follow in the implementation of public administration, responsibility. It also describes the historical development of administrative law, the contribution of scientists and lawyers to its development, the relationship between administrative law and constitutional law, other branches of law, its place in the legal system of the country, influence on other branches of science, interaction with other legal and scientific fields. Possible division of institutes of general part of administrative law is possible (Deviatnikovaitè, 2009): 
- the Institute of Public Administration: includes the establishment of the system of public administration institutions, relations between subjects of public administration, their establishment, liquidation, reorganization, coordination relations; as well as the content of the activities of public administration entities, incl. y. the functions, the areas in which they operate, the principles of public administration on the basis of which they operate, the legal framework governing their administrative legal status;

- the Civil Service Institute: it is the aspects of the acquisition, loss, civil servant, material liability of a civil servant, social guarantees, the system of legal acts regulating public service;

- Institute for Control of Activities of Public Administration Entities: parliamentary supervision of the executive power by the Parliament; supervision of the executive by the President, Government control of ministries, institutions under the ministries, Government agencies, administrative supervision of municipalities, State audit by the National Audit Office, powers of the Competition Council and the like;

- Institute for the Supervision of Public Administration Entities in respect of non-Personnel Persons - application of administrative impact measures, types of administrative violence measures, supervision methods, measures, forms, objectives. An institute of administrative responsibility may be distinguished;

- the Institute of Quasi-Legal Control of Public Administration Activities: it is the means and possibilities to appeal against the possible illegitimate decision of the public entity, the appropriateness of the behaviour (competence of the Administrative Dispute Commissions, Tax Disputes Commission, Parliament (Seimas) Ombudsmen, decisions);

- the Institute of Judicial Control of the Lawfulness of Activities of Public Administration Entities: activities of administrative courts for verification of compliance of public entity decision with higher legislation and others.

Professor A. Andriškevičius classified institutes of administrative law as follows: Institute of regulation of government organisation, Institute of regulation of administrative activities, Institute of Regulation of administrative punishment and Institute of administrative disputes (Andriuškevičius, 2008).

Special part of administrative law unites legal norms, institutes regulating public relations in specific areas of public administration activities: energy, industry, science, education, agriculture, competition, tax, health care, economy, agriculture, culture, registers, social guarantees, licensing, patenting, certification, environmental protection, asylum, spatial planning, consumer protection and other areas (Deviatnikovaite, 2009). The institutes of the special part of this branch of administrative law may change. It depends on the relevance and the needs of the time.

After Lithuania's accession to the European Union and its commitment to take over its entire acquis communautaire, the whole Lithuanian legal system, together with administrative law, has been transformed. Implementation of the provisions of the European Union legislation in Lithuanian law has become a priority. The abundance of administrative legal regulation at European Union level, the need for its application in the case-law raises challenging tasks for administrative law science. Effective implementation of European Union legislation in the systems of state power and public administration in Lithuania, 
analysis of administrative legal systems of the Member States of the European Union, search for similarities and differences, defines of personal rights and legitimate interests, when a Member State misapplies (refuses) the provisions of European Union legislation, the competence of national courts to deal with damages where, for example, damage caused by improper application of European Union law is made by a court of final instance in the State, and other issues are the subject of modern administrative law research.

The analysis of the relationship between administrative law and European Union law became relevant after Lithuania joined the European Union in 2004. Of course, this area wasn't left unnoticed by Lithuanian administrative law scientists. V. Valančius and S. Kavalne "The implementation of European Union law in the administrative law of Lithuania" (Valančius, Kavalnè, 2009) is the first publication in Lithuania to discuss a wide spectrum of administrative and European Union law relations. V. Valančius also presented his insights on the subject of administrative and European Union law in scientific publications (Valančius, 2007), which deal with issues of application of the norms of European Union law in administrative courts; violation of European Union law by national courts. In 2017, Deviatnikovaite published a comprehensive study on administrative law of foreign countries and the European Union (Deviatnikovaite, 2017). At the end of XX century the highly active European integration processes did not spur Lithuania. In order to belong to one of the largest economic and political community in Europe - the European Union - Lithuania has committed to adopt its entire acquis, so-called acquis communautaire, to bring it into line with national legislation. Thus, in essence, the whole legal system, without distinction of administrative law, has been subject to change. Lithuanian administrative law must implement plenty of European Union directives or regulations, and complete legal regulation of public administration. Due to the very large scope of the European Union acquis in the area of administrative law, it is particularly difficult to absorb it properly, and with the extension of the legal framework, the workload of the institutions applying European Union law has been greater. Nevertheless, from the very beginning of the European Union membership, Lithuanian public administration institutions have to apply European Union law in the area of administrative law and administrative courts in case and decision-making follow the extensive jurisprudence of the European Union judicial authorities (European Court of Justice and General Court) on the interpretation of European Union legislation and validity issues. European Union law works in almost all areas of administrative law. Traditionally, economic administrative law has the greatest impact. This is evident in the field of tax law, competition law, state aid, subsidy law. However, the classical areas of administrative law, such as agriculture, environmental administrative law, police, aliens, refugees, state responsibility, are increasingly permeated by European Union law. Particularly influential is the directly applicable European Community law, which is abundant, for example, in the field of fund administration, state aid (Valančius, Kavalne, 2009).

When implementing the requirements of the European Union legal acts in the Lithuanian legal system, mistakes are inevitable. Lithuanian euro integration has such an influence on administrative law that some of these laws are drafted and adopted in a hurry. It is obvious that all cases of application of European Union law in Lithuanian administrative law raise challenging tasks for administrative law science, which is forced to 
change attitudes towards administrative law as part of the national legal system and to investigate it, to analyse the obligations of Lithuania to implement European Union law during European integration, context. Thus, the issues of administrative law research have become such as the effective implementation of European Union legislation in the systems of state power and public administration of Lithuania, analysis of administrative legal systems of the Member States of the European Union, search for similarities and differences, effective protection of the rights and legitimate interests of a person when a member state misapplies (refuses) the provisions of European Union law, which courts should deal with damages, for example, damage caused by improper application of European Union law by a court of final instance in the state, and so on. All these issues should become topical objects of modern administrative law research, because extensive administrative legal regulation at the European Union level requires especially precise, thorough and effective implementation and application in Lithuania. Implementation of this task is impossible without conceptual theoretical justification.

The question is whether it would be more efficient to unify or harmonize the administrative law of the Member States and thus ensure its uniform application. In addition, common administrative law mechanisms have already become a practical necessity. However, there are a number of major obstacles that are still encountered in trying to establish a single European Union administrative law. First of all, it is too small a number of legal mechanisms to directly implement European Union law. If the European Union, as a new legal order, is to ensure that the principles of supremacy and direct validity are respected, it must have its own means to implement these principles. This is a sensitive issue, because European Union law is directly administered in a rather narrow manner (essentially the work of the European Commission as an institution of the European Union). The vast majority of European Union law today is implemented with the help of national administrations. Another problem that still exists is the resistance of national legal systems to the idea of European administrative law. This is influenced by psychological (routine, national pride, etc.), professional and technical (different legal terminology and legal thinking, huge differences between countries based on common and continental law traditions, language problem), political (unwillingness of national parliaments to fully accept international conferences) projects, etc.) issues. The process of harmonization is particularly complicated in countries where the national constitutional concept of law has a strong influence on administrative law. The third problem is the unequal interpretation of legal principles and legal norms in different countries. Even a fundamentally homogeneous legal concept, interpreted in accordance with the national law of different countries, can have complex expressions.

Still in the Lithuanian doctrine of administrative law there are some researches about global administrative law (Bilevičiūtè, Kosmačaitè, 2013). Global administrative law is a new phenomenon not only in Lithuanian legal life, but also in the world, although the proponents of the latter theory are discovering sources related to this novel in the XIX century.

B. Kingsbury, N. Krisch, R.B. Stewart, J.B. Wiener can be legitimately named as the originator of global administrative law. They argue that the concept of global administrative law begins with two interrelated ideas that proclaim that global governance 
can be understood as administration, and that such administration is often organized and shaped in accordance with the principles of administrative law. In this way, institutions that were not originally created as regulators are increasingly becoming such. These global governance bodies include intergovernmental institutions, informal intergovernmental networks, national government agencies operating under global standards, hybrid public and private sector bodies involved in international administration, and purely private organizations with a public role in international governance. Global administrative law includes legal mechanisms, principles and practices that promote or otherwise seek to influence the status of global administrative bodies, in particular by ensuring that these institutions meet adequate standards of transparency, performance, rationality, supervision and legality, and are able to make effective decisions and rules (Kingsbury et al., 2005). Thus, this theory analyses how international actors can successfully implement administrative-regulatory functions, and if such functions are performed by public authorities, their nature would obviously be administrative, but it is not possible to evaluate these entities in the context of classical administrative law, because the scope of their activities is international.

So, global administrative law is a field of public law that challenges classical international law and claims that the latter is no longer able to meet the needs of the modern world community and is therefore being declared a verdict and is gradually being offered a shift to global law. The goal of global administrative law is to create universal - international norms (norms - conglomerates), which would consolidate common principles of state governance and form transnational governance institutions, which would be assigned the implementation of administrative functions on a global scale. This phenomenon reflects the processes of legal integration and the creation of a global legal space that operates in accordance with the principles of administrative law. The Lithuanian administrative law as parts of European administrative law also is the parts of global administrative law.

\section{Conclusions}

The science of administrative law is described as an integral part of Lithuanian law science, where the specialists of administrative law - scientists investigate the essence of this branch of law, the subject of its regulation and separate institutes and in general the problems of administrative legal practice and science of the whole country. The development of administrative law, as well as administrative law science, is influenced by various political, economic, legal, socio-cultural and other social factors of a single whole. Each of these factors has different implications for the law of administrative law and presents different tasks to it, not always their influence on the development of the science of administrative law is positive (e. g. the Soviet regime in Lithuania in 1940-1990), but in the democratic, based on the protection of human rights and freedoms. In their pursuit, in society, they provide the basis for the development of administrative law science and its adaptation to changing political, economic and social conditions.

Today, the science of administrative law is delighted with its achievements: the research work of individual branches of administrative law, institutes, textbooks of the general part of administrative law is published, plenty of publications have been prepared, and several dissertations have been defended. In addition to analysing 
the current problems of regulation and application of administrative law in the country, the research also criticizes the administrative law science itself. It is to be welcomed that the Lithuanian law of administrative law tends to apply administrative processes in a more effective direction of protection of human rights and freedoms.

Lithuanian scientists understand the administrative law in broad sense as law of management and described quite wide range of its regulation subjects. After Lithuania's accession to the European Union and its commitment to take over its acquis communautaire, the entire Lithuanian legal system, together with administrative law, had to adapt to change. Implementation of the provisions of the European Union legislation in Lithuanian law has become a priority. The abundance of administrative legal regulation at European Union level and the need for its application in the case-law have created challenging tasks for administrative law science. An accurate analysis of the implementation of European Union legislation in the systems of state power and public administration in Lithuania, analysis of administrative legal systems of the Member States of the European Union, search for similarities and differences, effective defence of the rights and legitimate interests of a person when a Member State misapplies (waives) the provisions of European Union legislation, the jurisdiction of national courts to deal with damages where, for example, damage caused by inappropriate application of European Union law is made by a court of final instance in the state, and other issues become the subject of modern administrative law research.

Today, the following tasks of administrative law science are to be elaborated:

- purification of administrative legal categories (state administration, public administration, executive power, social management, presidential power, etc.);

- advocating the application of administrative principles as a stabilizing, regulating, legal loophole, law-abolishing institution;

- conducting complex research on administrative law in the context of its social changes;

- cooperation with other legal branches and other sciences (economics, political science, philosophy, sociology, social work, management, psychology, ethics);

- conducting new feasibility studies of social influence mechanisms (e. g. acculturation) in the implementation of administrative law norms;

- improvement of the concept of administrative process and elaboration of code of administrative process;

- research on the activities of public administration (public administration) institutions in such aspects as: distribution of state authority functions to state and territorial level state institutions, standardization of their activity bases and detailed regulation of activities, reform of public service, taking into account the need to reduce corruption, bureaucracy and arbitrariness of civil servants, personal increasing responsibility in the public service, the role of public opinion in legislation, etc.;

- increasing administrative law and the involvement of other scientists in the implementation of the reform of the legal system and the planning of legal regulation;

- transformation of administrative law in the context of globalization and integration into the European Union;

- development of specific sub-branches of administrative law. 


\section{Bibliography:}

1. Administracinè teisè: bendroji dalis. Kaunas : VDU, 1939. $150 \mathrm{p}$.

2. Andruškevičius A. Administracinè teisè: bendrieji teorijos klausimai, valdymo aktų institutas, ginčo santykių jurisprudenciniai aspektai. Vilnius : VI Registrų centras, 2008. 399 p.

3. Andruškevičius A. Administracinès teisès principai ir normų ribos. Vilnius : Teisinès informacijos centras, 2004. $271 \mathrm{p}$.

4. Andruškevičius A. Probleminiai administracinès teisès reguliavimo dalyko klausimai. Teise. 2002. № 42. P. 1-11.

5. Bakaveckas A. Administracinè teisè: teorija ir praktika. I dalis. Vilnius : MES, 2012. 464 p.

6. Bakaveckas A. Lietuvos vykdomoji valdžia. Vilnius : Eugrimas, 2007. 380 p.

7. Bilevičiūtè E. Lietuvos administracinès teisès mokslo raida. From Konstitucionalizmas ir teisés politika Europos Sajungoje / red. V. Šlapkauskas. Vilnius : MRU, 2013. P. 683-731.

8. Bilevičiūtė E., Kosmačaitė V. Globali administracinè teisè. From Konstitucionalizmas ir teisés politika Europos Sajungoje / red. V. Šlapkauskas. Vilnius : MRU, 2013. P. 616-648.

9. Čiočys P.A. Teisès pagrindai. Vilnius : Vilniaus vadybos aukštoji mokykla, 2008. 335 p.

10. Constitution of the Republic of Lithuania : adopted by the citizens of the Republic of Lithuania in the Referendum of 25 October 1992 / Grand Duchy of Lithuania. URL: http://www3.lrs.lt/home/Konstitucija/Constitution.htm.

11. Deviatnikovaitė I. Administracinè teisè: kategorijos, apibrèžimai, užduotys. Vilnius : Justitia, 2009. 216 p.

12. Deviatnikovaitė I. Užsienio šalių ir Europos Sajungos administracinè teisè. Vilnius : Registrų centras, 2017. 544 p.

13. Foreword Global Governance as Administration. National and Transnational Approaches to Global Administrative Law / B. Kingsbury, N. Krisch, R.B. Stewart, J.B. Wiener. Law\& contemporary problems. 2005. Vol. 68. № 3-4. P. 1-12.

14. Human Rights, the Rule of Law and Administrative Justice / R. Piličiauskas et. al. Vilnius, 2012. $791 \mathrm{p}$.

15. Kargaudienè A. Administracinès teisès pokyčiai šiuolaikinëje ir demokratinejje visuomeneje. Jurisprudencija. 2005. № 70(62). P. 31-41.

16. Lapinskas K., Petkevičius P. Tarybinè administracinè teisè. Vilnius : Mintis, 1980. 471 p.

17. Lietuvos administracinè teisè: bendroji dalis / A. Bakaveckas, A. Dziegoraitis, A. Dziegoraitienè, A. Gylys, R. Kalesnykas, E. Rusinas, B. Pranevičienė, S. Šedbaras, A. Urmonas, D. Žilinskas. Vilnius : MRU, 2005. 400 p.

18. Lietuvos Respublikos administracinių bylų teisenos istatymas (1999). URL: http://www.infolex.lt/portal/start_ta.asp?act=doc\&fr=pop\&doc=23225.

19. Lietuvos Respublikos administracinių teismų įsteigimo įstatymas : $1999 \mathrm{~m}$. sausio $14 \mathrm{~d}$. № VIII-1030. URL: https://e-seimas.lrs.lt/portal/legalAct/lt/TAD/TAIS.72291?jfwid=rivwzvpvg.

20. Lietuvos Respublikos ikiteisminio administracinių ginčų nagrinejjimo tvarkos įstatymas (1999). URL: http://www.infolex.lt/ta/102288.

21. Lietuvos Respublikos valstybès tarnybos ịstatymas. URL: http://infolex.lt/ta/17188.

22. Lietuvos Respublikos viešojo administravimo įstatymas : $1999 \mathrm{~m}$. birželio $17 \mathrm{~d}$. № VIII-1234. URL: https://www.e-tar.lt/portal/lt/legalAct/TAR.0BDFFD850A66/asr.

23. Lietuvos teisès istorija / V. Andriulis, M. Maksimaitis, V. Pakalniškis, J.S. Pečkaitis, A. Šenavičius. Vilnius : Justitia, 2002. 541 p.

24. Maksimaitis M. M. Riomerio mokslas apie valstybę. Vilnius : Lietuvos filosofijos ir sociologijos institutas, 1997. $195 \mathrm{p}$.

25. Maksimaitis M. Sovietmečio teisès mokslas Lietuvoje: laimèjimai ir praradimai. Justitia. 2007. № 3 (65). P. 69-77. 
26. Paužaitè-Kulvinskienė J. Administracinè justicija: teorija ir praktika. Vilnius : Justitia, 2005. 245 p.

27. Pranevičienè B. Kvaziteismai administracijos kontrolès sistemoje. Vilnius : LTU, 2003. $196 \mathrm{p}$.

28. Riomeris M. Konstitucinès ir teismo teisès pasieniuose. Vilnius : Pozicija, 1994. 200 p.

29. Smalskys V. Viešojo administravimo reformų raida atkūrus Lietuvos nepriklausomybę. From Regnum est. 1990 m. kovo 11-osios Nepriklausomybès Aktui-20. Liber Amicorum Vytautui Landsbergiui / red. G. Mesonis. Vilnius : MRU, 2010. P. 887-905.

30. Urbonas A. Administracinès jurisdikcijos ištakos Lietuvoje. Socialiniu mokslu studijos: mokslo darbai. 2009. № 3 (3). P. 317-331.

31. Urmonas A. Administracinè teisė socialinių pokyčių erdvejje. Jurisprudencija. 2006. № 5 (83). P. 48-55.

32. Urmonas A. Administracinès teisès socialinès sąveikos. From Regnum est. $1990 \mathrm{~m}$. kovo 11-osios Nepriklausomybès Aktui - 20. Liber Amicorum Vytautui Landsbergiui / red. G. Mesonis. Vilnius : MRU, 2010. P. 483-510.

33. Urmonas A. Administrative Law as a Macro-System Phenomenom. Social Sciences Studies. 2009. № 3(3). P. 273-287.

34. Urmonas A. Socialinių technologijų konceptualių modelių pritaikymo administracinèje teisèje paieška. Jurisprudencija. 2007. № 6 (96). P. 9-15.

35. Vaišvila A. Teisès teorija. Vilnius : Justitia, 2004. 527 p.

36. Valančius V. Europos Sajungos poveikis Lietuvos administracinei justicijai: tendencijų kontūrai. Jurisprudencija. 2007. № 7 (97). P. 33-38.

37. Valančius V., Kavalnė S. Europos Sajungos teisès igyvendinimas Lietuvos administracinëje teisèje. Vilnius : Registrų centras, 2009. 411 p.

38. Žilinskas D. Ar lipsime ị medị iš viršaus? Justitia. 2000. № 1. P. 35-37.

\section{References:}

1. Administracinė teisè: bendroji dalis [Administrative law: general part]. (1939). Kaunas: VDU [in Lithuanian].

2. Andruškevičius, A. (2008). Administracinė teisè: bendrieji teorijos klausimai, valdymo aktų institutas, ginčo santykių jurisprudenciniai aspektai [Administrative law: general theoretical issues, institute of management acts, legal aspects of conflict relationships]. Vilnius: VI Registrų centras [in Lithuanian].

3. Andruškevičius, A. (2004). Administracinès teisès principai ir normų ribos [Principles and boundaries of norms of administrative law]. Vilnius: Teisinès informacijos centras [in Lithuanian].

4. Andruškevičius, A. (2002). Probleminiai administracinès teisès reguliavimo dalyko klausimai [Problem aspects of administrative law regulation subject]. Teise, no. 42, pp. 1-11 [in Lithuanian].

5. Bakaveckas, A. (2012). Administracinè teisè: teorija ir praktika. I dalis [Administrative law: theory and practice. Part I]. Vilnius: MES [in Lithuanian].

6. Bakaveckas, A. (2007). Lietuvos vykdomoji valdžia [Executive government in Lithuania]. Vilnius: Eugrimas [in Lithuanian].

7. Bilevičiūtè, E. (2013). Lietuvos administracinès teisès mokslo raida [Development of administrative law science in Lithuania]. Šlapkauskas V. (ed.) From Konstitucionalizmas ir teisés politika Europos Sajungoje. Vilnius: MRU, pp. 683-731 [in Lithuanian].

8. Bilevičiūtè, E., Kosmačaitè, V. (2013). Globali administracinè teisè [Global administrative law]. Šlapkauskas V. (ed.) From Konstitucionalizmas ir teisés politika Europos Sajungoje. Vilnius: MRU, pp. 616-648 [in Lithuanian]. 
9. Čiočys, P.A. (2008). Teisès pagrindai [Basics of law]. Vilnius: Vilniaus vadybos aukštoji mokykla [in Lithuanian].

10. Grand Duchy of Lithuania (1992). Constitution of the Republic of Lithuania: adopted by the citizens of the Republic of Lithuania in the Referendum of 25 October 1992. Retrieved from: http://www3.lrs.lt/home/Konstitucija/Constitution.htm [in English].

11. Deviatnikovaitė, I. (2009). Administracinè teisè: kategorijos, apibrěžimai, užduotys [Administrative law: categories, definitions, tasks]. Vilnius: Justitia [in Lithuanian].

12. Deviatnikovaite, I. (2017). Užsienio šalių ir Europos Sajungos administracinè teisè [Administrative law of foreign countries and European Union]. Vilnius: Registru centras [in Lithuanian].

13. Kingsbury B. et al. (2005). Foreword Global Governance as Administration. National and Transnational Approaches to Global Administrative Law. Law\& contemporary problems, vol. 68, no. 3-4, pp. 1-12 [in English].

14. Piličiauskas R. et. al. (2012). Human Rights, the Rule of Law and Administrative Justice. Vilnius [in English].

15. Kargaudienè, A. (2005). Administracinès teisès pokyčiai šiuolaikinëje ir demokratinëje visuomeneje [Changes of administrative law in modern and democratic society]. Jurisprudencija, no. 70(62), pp. 31-41 [in Lithuanian].

16. Lapinskas, K., Petkevičius, P. (1980). Tarybinè administracinè teisè [Soviet administrative law]. Vilnius: Mintis [in Lithuanian].

17. Bakaveckas, A. et al. (2005). Lietuvos administraciné teisè: bendroji dalis [Lithuanian administrative law: general part]. Vilnius: MRU [in Lithuanian].

18. Grand Duchy of Lithuania (1999a). Lietuvos Respublikos administraciniu bylu teisenos istatymas [Administrative Procedure Law of Republic of Lithuania]. Retrieved from: http://www.infolex.1t/portal/start_ta.asp?act=doc\&fr=pop\&doc=23225 [in Lithuanian].

19. Grand Duchy of Lithuania (1999b). Lietuvos Respublikos administraciniu teismų ịsteigimo įstatymas: 1999 m. sausio 14 d. № VIII-1030 [Administrative Courts’ Establishment Law of Republic of Lithuania of 14 January 1999 № VIII-1030]. Retrieved from: https://e-seimas.lrs.lt/portal/legalAct/lt/TAD/TAIS.72291?jfwid=rivwzvpvg [in Lithuanian].

20. Grand Duchy of Lithuania (1999c). Lietuvos Respublikos ikiteisminio administraciniu ginčų nagrinėjimo tvarkos ịstatymas [Pre-trial Examination of Administrative Disputes Law of Republic of Lithuania]. Retrieved from: http://www.infolex.lt/ta/102288 [in Lithuanian].

21. Grand Duchy of Lithuania (2002). Lietuvos Respublikos valstybès tarnybos istatymas [Civil Servants Law of Republic of Lithuania]. Retrieved from: http://infolex.lt/ta/17188 [in Lithuanian].

22. Grand Duchy of Lithuania (1999d). Lietuvos Respublikos viešojo administravimo istatymas: 1999 m. birželio 17 d. № VIII-1234 [Public administration Law of Republic of Lithuania of 17 June 1999 № VIII-1234]. Retrieved from: https://www.e-tar.lt/portal/lt/legalAct/ TAR.0BDFFD850A66/asr [in Lithuanian].

23. Andriulis, V. et al. (2002). Lietuvos teisės istorija [History of law of Lithuania]. Vilnius: Justitia [in Lithuanian].

24. Maksimaitis, M. (1997). M. Riomerio mokslas apie valstybę [Research about state of M. Riomeris]. Vilnius: Lietuvos filosofijos ir sociologijos institutas [in Lithuanian].

25. Maksimaitis, M. (2007). Sovietmečio teisès mokslas Lietuvoje: laimëjimai ir praradimai [Law science in Lithuania in Soviet times: achievements and looses]. Justitia, no. 3(65), pp. 69-77 [in Lithuanian].

26. Paužaitè-Kulvinskienė, J. (2005). Administracinè justicija: teorija ir praktika [Administrative justice: theory and practice]. Vilnius: Justitia [in Lithuanian]. 
27. Pranevičienè, B. (2003). Kvaziteismai administracijos kontrolès sistemoje [Quasi-court institutions in administrative control system]. Vilnius: LTU [in Lithuanian].

28. Riomeris, M. (1994). Konstitucinès ir teismo teisès pasieniuose [Borders of constitutional and court law]. Vilnius: Pozicija [in Lithuanian].

29. Smalskys, V. (2010). Viešojo administravimo reformų raida atkūrus Lietuvos nepriklausomybę [Reforms of public administration after restoration of independence of Lithuania]. Mesonis G. (ed.) From Regnum est. 1990 m. kovo 11-osios Nepriklausomybès Aktui - 20. Liber Amicorum Vytautui Landsbergiui. Vilnius: MRU, pp. 887-905 [in Lithuanian].

30. Urbonas, A. (2009). Administracinès jurisdikcijos ištakos Lietuvoje [Origins of administrative jurisdiction in Lithuania]. Socialiniu mokslu studijos: mokslo darbai, no. 3(3), pp. 317-331 [in Lithuanian].

31. Urmonas, A. (2006). Administracinè teisè socialinių pokyčių erdvèje [Administrative law in area of social changes]. Jurisprudencija, no. 5(83), pp. 48-55 [in Lithuanian].

32. Urmonas, A. (2010). Administracinès teisès socialinès sąveikos [Social interconnection of administrative law]. Mesonis G. (ed.) From Regnum est. $1990 \mathrm{~m}$. kovo 11-osios Nepriklausomybes Aktui - 20. Liber Amicorum Vytautui Landsbergiui. Vilnius: MRU, pp. 483-510 [in Lithuanian].

33. Urmonas, A. (2009). Administrative Law as a Macro-System Phenomenom. Social Sciences Studies, no. 3(3), pp. 273-287 [in English].

34. Urmonas, A. (2007). Socialinių technologijų konceptualių modelių pritaikymo administracineje teiseje paieška [Searching for the application of conceptual models of social technologies in administrative law]. Jurisprudencija, no. 6(96), pp. 9-15 [in Lithuanian].

35. Vaišvila, A. (2004). Teisès teorija [Theory of law]. Vilnius: Justitia [in Lithuanian].

36. Valančius, V. (2007). Europos Sajungos poveikis Lietuvos administracinei justicijai: tendencijų kontūrai [Influence of European Union law at administrative law of Lithuania]. Jurisprudencija, no. 7(97), pp. 33-38 [in Lithuanian].

37. Valančius, V., Kavalnè, S. (2009). Europos Sajungos teisès igyvendinimas Lietuvos administracineje teiseje [The implementation of European Union law in the administrative law of Lithuania]. Vilnius: Registrų centras [in Lithuanian].

38. Žilinskas, D. (2000). Ar lipsime ị medị iš viršaus? [Will we tackle the tree from top?]. Justitia, no. 1, pp. 35-37 [in Lithuanian].

\title{
РОЗВИТОК АДМІНІСТРАТИВНОГО ПРАВА ТА АДМІНІСТРАТИВНО-ПРАВОВОЇ ДОКТРИНИ В ЛИТВІ
}

\author{
Егле Білявічюте, \\ професор юридичного факультету \\ Інституту публічного права \\ Університету Миколаса Ромеріса, \\ доктор юридичних наук, професор \\ orcid.org/0000-0003-4142-3774 \\ eglek@mruni.eu; eglutebil@gmail.com
}

Система національного права та відповідна система демократичної влади повинна гарантувати оптимальний захист основних прав $i$ свобод людини та допомагати створювати добробут людей. Наука адміністративного права постійно розвивається, ї̈ погляди мають стратегічний характер та орієнтовані на майбутнє. Часто йде боротьба за впровадження або заперечення нових ідей, думок, концепиій і парадигм. Нові, старі, 


\section{ЗАРУБІЖНЕ АДМІНІСТРАТИВНЕ ПРАВО ТА ПРОЦЕС}

неточні твердження змінені, щуоб бути більи точними, нові ідеї-щуоб критикувати старі й життєві практики, ставити нові проблеми, на які наука повинна раціонально відповідати. Наука про адміністративне право в Литві не стоїть на місиі, вона постійно змінюється внаслідок зміни самого адміністративного права. Поняття адміністративного права змінюється, його регулювання розширюється. Наука про адміністративне право $\epsilon$ невід 'ємною частиною литовської юридичної науки, де фахівці з адміністративного права досліджують суть иісї галузі, ї̈ предмет та окремі інститути, усі актуальні проблеми адміністративно-правової практики й науки.

Представлена статтяє першим науковим дослідженняму циклі «Розвитокадміністративного права та адміністративно-правової доктрини в Литві». Мета статmi-розкрити розвиток адміністративного права та доктрини адміністративного права в Литві з 1990 р. шляхом аналізу робіт литовських учених у иій галузі за категоріями, щзо визначені в завданнях дослідження. Для досягнення мети необхідно виконати такі завдання: коротко представити й обговорити розвиток литовського адміністративного права, науки та адміністративного праваяк категорії; визначити й проаналізувати иілі адміністративного права, предмет регулювання та систему адміністративного права в Литві. Для досягнення мети й завдань дослідження було проведено аналіз праць литовських учених та основних законів, які здійснюють адміністративно-правове регулювання в Литві.

Методи. Під час дослідження використано історико-порівняльний, документальний аналіз, синтез та інші методи.

Результати дослідження показали, що в Литві є сучасне адміністративне право та система адміністративного правосуддя, що відповідає вимогам стандартів правосуддя Свропейського Союзу.

Висновки. За результатами дослідження можна зробити висновок, щуо литовські вчені розуміють адміністративне право в широкому сенсі як правове регулювання та описують досить широке коло питань, які воно розглядає. Після вступу Литви до Свропейського Союзу та набуття його асquis соттипаиtaire вся правова система Литви разом 3 адміністративним законодавством повинна була адаптуватися до змін. Імплементація положень законодавства Європейського Союзу взаконодавство Литви стала пріоритетним завданням. Велика кількість адміністративно-правового регулювання на рівні Свропейського Союзу та необхідність його застосування в судовій практиці створили складні завдання для науки адміністративного права. Точний аналіз застосування законодавства Свропейського Союзу у сфері державної влади й державного управління в Литві, аналіз адміністративноправових систем у державах - членах Європейського Союзу, пошук схожих і відмінних рис, ефективний захист прав $i$ законних інтересів особи, коли держава-член неправильно застосовує (відмовляється) від положень законодавства Свропейського Союзу, юрисдикиія національних судів щодо розгляду збитків (наприклад, збитку, викликаного неналежним застосуванням державою законодавства Свропейського Союзу) та інші питання стають предметом дослідження сучасного адміністративного права.

Ключові слова: адміністративно-правова наука, адміністративне право, державне управління, адміністративне правосуддя, правова доктрина. 